\title{
On the Effect of Salts on the Assimilation of Carbon Dioxide in Ulva latissima, $L$.
}

BY

\author{
E. A. NEWELL ARBER, B.A., \\ Trinily College, Cambridge, University Demonstrator in Palaeabotany.
}

\section{SECtion I. Method.}

$\mathrm{T}$

$\mathrm{HE}$ primary object of this research was to obtain some idea of the extent to which the power of carbonassimilation is dependent on the absorption of nutrient salts, and of the inhibition caused by the presence or absence of certain salts in the medium. The experiments were intended to be primarily qualitative rather than quantitative, and the standpoint throughout was the power of carbon-assimilation, and not growth or development.

For this purpose a plant possessing a minimum of specialization in regard to both carbon-assimilation and absorption was beşt suited. Certain marine Chlorophyceae present an additional advantage in that they grow in a medium containing an exceedingly constant proportion of dissolved salts. The Alga used throughout this work was Ulva latissima, Linn. Enteromorpha intestinalis, Link., was also tried, but presented difficulties which were for the most part absent in the case of Ulva, and for this reason was early abandoned.

The method employed was to obtain Ulva free from starch, and then to expose it to light for various periods in solutions of known composition. The amount of starch formed in each 


\section{Arber.-On the Effect of Salts on the Assimilation}

case was taken as a measure of the carbon-assimilation during the period of exposure.

The Ulva I used was partly obtained from the Welsh coast at Bangor through the kindness of Professor Phillips, and partly from Hunstanton on the Norfolk coast. I found that the Alga succeeded best when gathered as near the low tide limit as possible. Another point of great importance was that it should be free from other kinds of seaweed. The Ulva was placed in sea water in large earthenware vessels, in a cool dark room in the laboratory. The temperature of this room was at the end of April about $16^{\circ}-18^{\circ} \mathrm{C}$. at midday; at the end of June between $18^{\circ}-20^{\circ} \mathrm{C}$., or even higher. The sea water was supplied by the Great Eastern Railway from the coast at Lowestoft. The specific gravity of two samples was taken and found to be (I) 1.026 ; (2) I.0254. The average specific gravity of sea water is about I.027. The samples were therefore slightly lower than they should have been, but the difference is so small as to be negligible.

The chief difficulty experienced in this work was to keep the Alga in good condition during the prolonged period of darkening that was necessary to get rid of all accumulated starch. During the winter and spring this difficulty was not so great, but in May and June it was found to be almost impossible to preserve the Algae in a healthy state, although the period of darkening was then shorter. This difficulty was undoubtedly one of temperature. Modern work ${ }^{1}$ has shown that these Algae require a comparatively low temperature; in fact, as cool a situation as possible. I had no means at my command for keeping down the temperature in

\footnotetext{
1 During the last decade considerable attention has been directed to the best phosical conditions and mediums in which to cultivate marine and freshwater Algae. Attention may be called to the following works:-Klebs ('96), Oltmanns ('92 and '95), Noll (92), Ward ('99), Molisch (95). References to the works quoted will be found in the Bibliography at p. 69, at the end of this paper. The numbers in brackets after the anthors' names indicate the year of publication of the work referred to in the Bibliography. Thus Noll ('92) means that the paper was published in 1892 .
} 


\section{of Carbon Dioxide in Ulva latissima, L. . 41}

any way for a long period, or for the large amount of material which was necessary for the work. Another difficulty, which also was no doubt partly due to the difficulty with temperature, was the enormous increase of Bacteria during the period of darkening. These Bacteria also make their appearance, but in a less degree, in cultures exposed to light, as has been recorded by Benecke ${ }^{1}$ and Oltmanns ${ }^{2}$. In darkness, however, this becomes a matter of great difficulty. In less than a week, a most evil-smelling scum, white or brick-red in colour, and of appreciable thickness, makes its appearance on the surface. It is of course impossible to sterilize the sea water, and the only thing to be done is to constantly change the water at least three times a fortnight, and to skim the surface every other day. When the sea water was changed the Algae were rinsed thoroughly with tap water and drained in a sieve, and then put into a fresh basin of sea water. That the formation of the scum was largely due to the temperature, was proved by the fact that in June it was much greater than in March. It may be pointed out, as indeed Oltmanns, Noll, and others have shown, that the changing of the sea water is an absolute necessity in other ways, as by so doing a fresh supply of nutrient salts is brought within the reach of the plant. Another difficulty was found to be very common in cultures carried out in the summer months. The Alga seemed then to be more liable to lose its chlorophyll than in the spring, probably owing to the greater intensity and duration of the illumination on exposure in the greenhouse. On the whole, winter work, with longer darkening and less constant illumination, was found to give better results. In consequence of these difficulties I was unable in some cases to make as many experiments or to extend the work as far as I could have wished.

It was found to be fairly easy to tell, as a rule, when Ulva was in an unhealthy condition. Under adverse circumstances the Alga would become full of holes (as may be seen naturally

1 Benecke ('98).

I Oltmanns ('95). 


\section{Arber.-On the Effect of Salts on the Assimilation}

in old specimens), and the thallus would fragmentate into small pieces, or the solution become cloudy. Side by side with this the chlorophyll would disappear; although this sometimes took place before fragmentation.

The period of darkening required to obtain the Ulva starch-free was much greater than was at first anticipated. In the winter and spring months a period of five weeks or longer had to be allowed. After a month, however, most of the starch had disappeared. In May and June the period was shorter; no doubt as a result of the higher mean temperature. In three weeks to a month all the starch had disappeared. The Alga was tested from time to time, and if after two or three testings no starch was found, it was at once used for exposure experiments.

Experiment I. Ulva darkened Feb. 24, I900.

\begin{tabular}{|c|c|l|}
\hline Date. & Days. & \multicolumn{1}{|c|}{ Amount of Starch. } \\
\hline Feb. 26 & 2 & maximum \\
Mar. 10 & 14 & large \\
Mar. 18 & 22 & moderate \\
Apr. 7 & 42 & a trace \\
Apr. 9 & 44 & none or the slightest trace \\
Apr. II & 46 & none \\
Apr. 15 & 50 & none \\
\hline
\end{tabular}

Evell after such prolonged darkening it was sometimes found that a small part of the thallus still retained a trace. A fact which was noticed throughout, and which I am unable to explain, was that when only a trace of starch was present, either as a residuum of darkening or as a minimum of carbonassimilation, such starch was almost invariably to be found only at the edges of the thallus, and in this position there was in nearly all cases more starch than in the centre even when a moderate amount was present.

Another point observed in connexion with the darkening was the change in colour of the thallus when exposed to light 
of Carbon Dioxide in Ulva latissima, L. 43

after darkening for some time. In the latter case the Alga was a dull, fairly opaque, dark green. On illumination of even a day it became much lighter in colour as well as more transparent-a brighter green generally. Harvey ${ }^{1}$ has made the same remark about specimens of Ulva dredged from deep water, when 'the colour is of a very dark and even bluish green reflecting glaucous tints when under water.'

Enteromorpha intestinalis, Link., required an even longer period of darkening. In the spring not less than two months was found necessary, and even then one could not always be sure that every trace of starch had been got rid of. It was also found to be much more difficult to judge accurately the amount of starch in this Alga as compared with Ulva, and for these reasons it was early abandoned.

The method of testing for starch used was Sachs's iodine reaction ${ }^{2}$. Ulva when in a healthy state decolorized easily, after being placed in boiling water for a minute or two, and then allowed to stand for a day in methylated spirit. A sufficient strength of watery alcoholic solution of iodine was used without perceptibly colouring the thallus yellow. In a few cases Schimper's chloral hydrate method was used as a confirmatory test. Sachs's iodine method with this Alga is, however, sufficiently delicate, and this plant had the great advantage that, by this method, the distribution of the starch over a considerable area of thallus could be estimated at a glance. The drawback with regard to Ulva consists in the extremely small size of the cells even under the ordinary high power ( $\frac{1}{6}$ inch objective) of the microscope. Experiments with plasmolysis were not attempted, and they would be very difficult if not impossible for this reason. As might be expected, the appearance of the chloroplast was, as a rule, no guide to the condition, satisfactory or otherwise, of the Alga.

When the Alga had been rendered starch-free, it was exposed to light continuously in a cool greenhouse, which

' Harvey ('46), vol. 4, under Utua latissitna.

= Sachs ('88), p. I. 


\section{Arber.-On the Effect of Salts on the Assimilation}

was kept carefully shaded in summer. The medium, or solution of salts, was contained in glass dishes holding about 700 c.c., and about 2 inches deep and 5 inches in diameter. The members of a series of experiments with different degrees of concentration of a salt and comparative experiments, were exposed at the same time and for the same length of time, so that the temperature and illumination were constant.

Before the Algae were placed in these solutions they were thoroughly rinsed several times with tap water and finally soaked once or twice for a few minutes in distilled water to get rid, as far as possible, of all traces of the salts of sea water. A preliminary series of experiments was made in order to make sure that this washing, especially the use of distilled water, did not exercise a prejudicial effect on the Algae. As will be seen from Experiment II, this was not found to be the case.

Experimont II. Starch-free Ulva washed in

\begin{tabular}{|c|c|c|c|}
\hline & $\begin{array}{l}\text { Tap water, and then } \\
\text { Distilled water. }\end{array}$ & Tap water only. & $\begin{array}{l}\text { Control in sea } \\
\text { water direct. }\end{array}$ \\
\hline Days. & \multicolumn{3}{|c|}{ Artount of Starck. } \\
\hline 1 & moderate & moderate & moderate \\
\hline 3 & moderate-large & moderate & moderate-large \\
\hline 5 & large & large & moderate \\
\hline
\end{tabular}

This result was confirmed by other experiments.

Special mention must be made of the way in which the amount of starch formed under different conditions was compared. It was found easy to judge this by the eye, by paying attention to the distribution and the intensity of the colour obtained by the iodine reaction. I used an arbitrary scale of five degrees as follows :- 


\section{of Carbon Dioxide in Ulva latissima, $L$.}

I. Maximum: thallus a uniform deep black.

2. Large: thallus black but starch not uniformily distributed, i. e. darker in some places than others.

3. Moderate: thallus bluish-black at the edges. Centre of the thallus blue, with less starch.

4. Little: thallus bluish at the edges with hardly a trace in the centre.

5. Trace: thallus only very faintly blue.

The following experiment, and the inferences drawn from .it, may serve to illustrate the use of the starch-scale, and its limitations in regard to reliable evidence.

Experiment III. Ulva (starch-free) in sea water,

\begin{tabular}{|c|c|l|}
\multicolumn{3}{|c|}{ January 19, 1900.} \\
\hline Date. & $\begin{array}{c}\text { Days' } \\
\text { Exposure. }\end{array}$ & Amount of Starch. \\
\hline Jan. 20 & 1 & a trace \\
Jan. 23 & 4 & a little \\
Jan. 29 & 10 & moderate \\
Feb. 2 & I4 & large \\
Feb. 6 & 18 & maximum \\
\hline
\end{tabular}

It will be noticed that the amount of starch increased for some time until the maximum was reached. Such a gradual increase was in greater or less degree common to all experiments under conditions where carbon-assimilation could take place freely, and is readily explained. At the end of the first day's illumination the amount of starch in the cells is that formed during the day. But after 12 days' exposure the amount of starch in the thallus is that formed during the $n^{\text {tb }}$ day, and what-remains of the starch formed during $n-$ J days. Consequently the iodine reaction after $n$ days gives a much deeper coloration, the 'maximum' of the starch-scale representing the maximum of starch-accumulation. I wish to specially emphasize the fact that Experiment III was not made with the intention of finding the time necessary for the formation of a 'moderate' or any other degree of starch. The testing was only performed on the days indicated, and not 


\section{Arber.-On the Effect of Salts on the Assimilation}

every day or at shorter intervals as would have been the case with such an object in view. The time required to reach any special point in the scale must obviously depend on external conditions, such as continued brightness of illumination, temperature, \&c., as well as on the vitality of the plant itself. The effect of these is seen in a comparison between Experiments II and III, the latter being performed in the depth of winter and the former at the end of April. The object of such an experiment as No. III was to show that Ulva in sea water can assimilate freely, and that a maximum of assimilation is . possible. This was the only kind of inference intended to be drawn from such experiments, and for this purpose the starchscale given above was found to be quite sufficient.

The work was carried on during the past year in the University Botanical Laboratory at Cambridge. I may here take the opportunity of expressing my great indebtedness to Mr. Francis Darwin, who first suggested the subject to me, and who has helped me throughout by suggestions as to scope and methods. I am also particularly indebted to him for help with a somewhat scattered literature.

\section{Section II. Distilled Water.}

Experiments with distilled water were especially interesting, as in such a medium there is of course a complete absence of nutrient salts. I found that it was only possible to keep. Ulva alive for a short time in distilled water. In the majority of cases, a certain amount of starch was formed, although the amount was never 'moderate.' Out of nine series of experiments, five showed a 'little' starch. In two others only a 'trace' of starch, while in the remaining two, no starch could be detected even after several testings.

The amount of starch in the control in sea water on the seventh day was 'large,' showing that the Alga was in good condition originally. The Alga used was darkened on March 24, 1900, nearly two months before the experiment, and had been proved starch-free by repeated testings. 
Experiment IV: April 19, I900. Starch-free Ulva in. distilled water.

\begin{tabular}{|c|c|c|}
\hline Date. & Days. & Amount of Starch. \\
\hline Apr. 20 & I & a trace \\
Apr. 21 & 2 & n little \\
Apr. 22 & 3 &,$"$ \\
Apr. 23 & 4 & $n$ \\
Apr. 24 & 5 &,$"$ \\
Apr. 25 & 6 &,$"$ \\
Apr. 26 & 7 &, \\
\hline
\end{tabular}

Usually after a week or even less in distilled water the Alga became unhealthy; the solution would become cloudy with Bacteria and the Alga fragmentate. I cannot but conclude, however, that this result was not due directly to the distilled water. Naegeli and others have found that distilled water has a poisonous or an injurious, if not fatal, action on plants. Naegeli ${ }^{1}$ attributed this to the presence of a trace of copper, and found that one part of copper in a thousand million parts of water was fatal to a Spirogyra filament. On the other hand, Klebs ${ }^{2}$, Oltmanns ${ }^{3}$, Molisch ${ }^{4}$, and others, have made use of distilled water in connexion with the cultivation of Algae without any disastrous results. The distilled water used in this work was the ordinary distilled water as supplied to the laboratory and not re-distilled, and was made use of in all my experiments wherever sea water or tap water were not employed. The fact that, whenever a sufficient amount of nutrient salts was added to such water, there was always, with the exception of a very small margin of failures, a greater or less amount of carbon-assimilationthe amount of starch often reaching the maximum-seemed to show conclusively that the distilled water in itself had no injurious effect. In Experiments IX-X (p. 6I) and XII-XIII (p. 64), the cultures were extended for fully a month.

1 Nacgell; vide Pfeffer (00), p. 23 I.

Oltmanns (92). 


\section{${ }_{4}^{8}$ Arber.-On the Effect of Salts on the Assimilation}

Another series of experiments, similar in nature to those above described, were made in which Ulva was suspended in damp air. Starch-free Ulva was carefully rinsed with distilled water to get rid of all traces of sea water, and then roughly dried by being gently pressed in filter paper. It was then placed on a dry earthenware plate covered with a large glass dish, and exposed to light in a greenhouse. After two days in the early part of June, rather more than a 'trace' of starch, i. e., almost a 'little,' was obtained in the two experiments made.

Another experiment was made in which the plate held some distilled water and the Alga was placed on a brass stand similar to those commonly used in the laboratory for holding slides. The Ulva was so arranged that it did not dip into the water in the plate and the whole was covered with a large glass dish as before. The Ulva was kept moist and the dish was covered with dew from the evaporation of the water. In five experiments out of six a similar result was obtained to that in the experiments last mentioned. The Alga did not seem to be able to survive such treatment for a longer period than two days. The results, however, agree very closely with those obtained when Ulva was immersed in distilled water.

The conclusion I arrived at from these experiments, was that the function of carbon-assimilation in Ulva was dependent on the presence of suitable inorganic salts in the medium. It seemed clear for the reasons already given that these results could not be attributed to any prejudicial effect of the distilled water as a medium, but that the inhibition of the carbon-assimilation was caused by the entire and continued absence of nutrient salts, just as much as it might have been by unsuitable physical conditions. As might be expected, a prolonged continuance of this condition was found to be fatal.

In most of the experiments with distilled water it was found that a small amount of carbon-assimilation was possible, but the amount of starch-accumulation was never 'moderate' 
in quantity. For reasons more fully expressed in Section V, I do not attribute this to an incomplete removal of all traces of sea water from the Ulva at the beginning of the experiment. These results can only, I think, be accounted for either by supposing that the carbon-assimilation can go on for a very short time in the total absence of inorganic nutrient salts, or that the small starch-accumulation is due to the presence of reserves of such salts within the plant. I am inclined to favour the latter hypothesis, since there is evidence to show that such reserves are constantly present in the plant. An experiment of de Saussure ', made more than a century ago, illustrates this fact. De Saussure placed some Peppermint plants with their roots in pure water, in a place exposed to air and light but sheltered from rain. After allowing them to vegetate for a period of two and a half months, he found that plants which originally weighed 100 parts had increased to 216 parts, and the total dry matter, originally 40.3 , had become 62 parts. It is obvious then that at least one-third of the ash of the original plants was in excess, and constituted a reserve which was drawn on during the two and a half months of culture in pure water.

The lack of knowledge of the nature and amount of the various inorganic reserves available within the plant was a constantly present difficulty throughout this work, and in this instance prevents any definite conclusion. The fact that a small amount of starch can be formed in the absence of nutrient salts, in no way invalidates the conclusion that a total inhibition of the carbon-assimilation can be caused by the continued absence of all the inorganic salts obtained by means of absorption.

\section{SECTION III. TAP WATER.}

Several experiments were made in which 'starch-free' Ulva was exposed to light in ordinary tap water, and the difference between these cultures and those in distilled water was very striking, and forms a good illustration of the fact

1 De Saussure; vide Johnson (69), p. 175.

E 
50 Arber.-On the Effect of Salls on the Assimilation

'that from ordinary tap water containing mere traces of salts, plants may collect large quantities of non-volatilizable mineral constituents, and that, moreover, these constituents are absorbed in proportions altogether different from those obtaining in the water in question 1.' The Cambridge tap water contains about .036 per cent. of total solids, of which the largest components are $\mathrm{CaCO}_{3}=.0118$ per cent. and $\mathrm{NaCl}=.003^{2}$ per cent. A typical experiment was as follows:-

Experiment $\nabla$. April II, Igoo. Ulva exposed in tap water.

\begin{tabular}{|c|c|l|}
\hline Date. & Days. & Amount of Starch. \\
\hline Apr. I3 & 2 & moderate \\
Apr. I5 & 4 & large \\
\hline
\end{tabular}

This result was confirmed by four other experiments, although in one or two cases I failed to obtain more than a 'little' starch. I concluded, therefore, that for some time at least there was no marked inhibition of carbon-assimilation when the medium was tap water. Experiments for a period longer than a week were not however successful; the Alga. becoming unhealthy and finally dying. In none of these experiments did I obtain the maximum of starch-accumulation. The larger amount of starch formed in a medium of tap water, as compared with distilled water, can only I think be accounted for by the fact that the former does contain some nutrient substances in however small proportions; and that the plant can make use of these to such a degree that for some time there is little inhibition of the carbon-assimilatory function, or at least only a very partial inhibition. If this is the case, we have here a striking illustration of the extent of the influence of nutrient salts on the power of carbon-assimilation.

These experiments would seem to throw some light on

1 Pfeffer (00), pp. I 20-1. 


\section{of Carbon Dioxide in Ulva latissima, L. $5 \mathrm{I}$}

the biology of Algae. It is well known for instance that certain Algae flourish in the estuaries of large tidal rivers, in localities which at low tide are practically freshwater. These results with tap water would seem to show_that even at low tide the carbon-assimilation is not inhibited but that it can go on even in very dilute solutions, until on the return of the tide the water becomes strongly saline again. It has been long known that some marine Algae can accommodate themselves to brackish water and ultimately to fresh water, if the process is gradual and prolonged. On the other hand, other Algae are obligate Halophytes, and will not thrive for any length of time in dilute solutions of nutrient salts. To which class Ulva belongs I am unable to speak positively or definitely, as I had not the time at my disposal for the long accommodatory experiments necessary to answer this question. Whatever evidence these experiments afford, seems rather in favour of the view that Ulva is more or less obligate, and in that case these experiments with tap water show that a habitat, which is exposed to short periods of almost fresh water conditions, would cause a very slight, if any, inhibition of the power of carbon-assimilation, even to obligate Algae.

\section{SECTION IV. SEA Water.}

Many cultures of Ulva were made in sea water, chiefly as controls to other experiments, and as a rule there was no difficulty in obtaining the maximum of starch accumulation. A 'moderate' amount of starch was usually formed in a couple of days or even less of bright weather, whereas in the case of Experiment III, in mid-winter, the period was much longer. The chief use of such controls, apart from comparison with other cultures as to the amount of starch formed, was to make sure that at the beginning of the experiment the material was in a healthy condition.

Sea water being the natural medium in which such Algae live, contains all the salts necessary for its life and 


\section{Arber.-On the Effect of Salts on the Assimilation}

development. A study of the composition of sea water is therefore important in itself.

Two analyses of British sea water may be quoted. Analysis $A$ was made by Thorpe and Moreton ${ }^{1}$ of water collected from the Irish Sea in winter (Sp. Gr. 1.02721 at $0^{\circ}$ ). Analysis $B$ is from water from the Bristol Channel (Sp. Gr. r.0274 at $15.5^{\circ} \mathrm{C}$. $)^{2}$.

The form of these analyses has been altered here in order to bring the salts into order of their percentages.

\begin{tabular}{|c|c|c|c|c|c|}
\hline \multicolumn{3}{|c|}{$\underset{\text { In } 1000 \text { parts. }}{A}$} & \multicolumn{2}{|c|}{ Per Cent. } & \multirow{2}{*}{$\begin{array}{c}\begin{array}{l}B \\
\text { Per Cent. }\end{array} \\
96.474\end{array}$} \\
\hline Water . &. & $966 \cdot 1_{4} 054$ & $=$ & 96.614 & \\
\hline I $\mathrm{NaCl}$. & . . & 26.43918 & $a$ & 2.644 & 2.706 \\
\hline$=\mathrm{MgCl}_{2}$. & $\cdot$. & $3 \cdot 15083$ & $=$ & 3 I 5 & .367 \\
\hline $3 \mathrm{Mg} \mathrm{SO}_{4}$. & . . & 2.06608 & $=$ & .207 & .230 \\
\hline $4 \mathrm{CaSO}_{4}$. & $\cdot \cdot$ & $\mathrm{I} \cdot 33^{1} 5^{8}$ & $=$ & .133 & $\cdot I_{4} I$ \\
\hline $5 \mathrm{KCl}$. & . . & $0.74^{619}$ & $=$ & .075 & .077 \\
\hline $6 \mathrm{Mg} \mathrm{Br}$. & . . & 0.07052 & $=$ &.$\infty 7$ &.$\infty 3$ \\
\hline $7 \mathrm{CaCO}_{3}$. & . . & 0.04754 & $\square$ &.$\infty 5$ &.$\infty 3$ \\
\hline $\mathrm{FeCO}_{2}$. & . . & 0.00503 & & & \\
\hline $\mathrm{Mg}\left(\mathrm{NO}_{2}\right)$ & , & $0 . \infty 207$ & & & \\
\hline $\mathrm{NH}_{4} \mathrm{Cl}$. & $\cdot \cdot$ & 0.00044 & & & \\
\hline Traces of $\mathbf{M g}$ & $\mathrm{CO}_{2} \mathrm{I}$ & $\mathrm{iCl}, \mathrm{SiO}_{2}$ & & & \\
\hline
\end{tabular}

In the present paper it is proposed to deal with the five principal salts in sea water ; the three chlorides $\left(\mathrm{NaCl}, \mathrm{Mg} \mathrm{Cl}_{2}\right.$, and $\mathrm{K} \mathrm{Cl}$ ), and the two sulphates $\left(\mathrm{Mg} \mathrm{SO}_{4}\right.$ and $\mathrm{CaSO}$ ). In a future communication I shall hope to give some account of the effect on carbon-assimilation of those salts which occur only as traces or in very small amounts in sea water. A brief resume of the chief results obtained from both these series of experiments was given before the British Association at the recent Bradford meeting ${ }^{8}$.

\footnotetext{
Tilden ('89), p. 67.

Thorpe and Moreton; vide Thorpe, p. 141. 


\section{Section V. Sodium Chloride.}

From the analyses of sea water quoted in the preceding section, it will be seen that sodium chloride forms by far the largest percentage (2.6-2.7 per cent.) of any of the salts in sea water, and this quantity is at least seven times larger than the amount of magnesium chloride ( 0.3 per cent.), the next largest constituent. A large number of experiments were made in which sodium chloride was alone present in the media, and to these reference will first be made. Starchfree Ulva was exposed in solutions of various strengths of the purest sodium chloride obtainable, dissolved in either distilled water or tap water. In every case, out of about thirty cultures with different percentages, a certain amount of starch was always found in the cells. Among the first of these experiments were those in which the amount of $\mathrm{NaCl}$ was the same as in sea water, i.e. 2.65 per cent. The results of two of the experiments, one with distilled water and the other with tap water as mediums, are as follows :-

Experiment VI. Feb. 2, 1900. Ulva in 2.65 per cent. $\mathrm{NaCl}$ in distilled water.

\begin{tabular}{|c|r|l|}
\hline Dale. & Days. & A mount of Slarck. \\
\hline Feb. 5 & 3 & moderate \\
Feb. II & 9 & large \\
Feb. 20 & I8 & large \\
\hline
\end{tabular}

Experiment VII. April 15, I900. Ulva in 2.5 per cent. $\mathrm{NaCl}$ in tap water..

\begin{tabular}{|c|c|l|}
\hline Date. & Days. & Amownt of Starch. \\
\hline Apr. 16 & $\mathrm{I}$ & moderate \\
Apr. 18 & 3 & large \\
Apr. 20 & 5 & large \\
\hline
\end{tabular}




\section{Arher.-On the Effect of Salts on the Assimilation}

Other similar experiments confirmed this. With regard to the duration of the experiments, eighteen days was the limit to which any of my cultures with $\mathrm{NaCl}$ were carried, and in this time I have never observed the maximum of starch storage in cultures of this or any other percentage of sodium chloride alone. The results with tap-water solutions of $\mathrm{NaCl}$ were very similar throughout to those with distilled water; if anything a little more starch was formèd.

Experiments were also made to find the percentage of sodium chloride which gave the best results in the way of starch-formation, and the effect of dilute and concentrated solutions of the same salt. Lesage ${ }^{1}$ is among the very few writers who have directly estimated the effect of the amount of salt $(\mathrm{NaCl})$ present in the soil on the power of starchformation ${ }^{2}$. Lesage found that the quantity of starch formed in the vegetative organs of Lepidium sativum was directly influenced by the amount of sodium chloride present. The maximum of starch-formation was reached when the plant was watered with a solution containing $2.5-5$ grams $\mathrm{NaCl}$ in a litre. The lower minimum was found to be I.6 grams per litre; and the upper, 12.5 grams $\mathrm{NaCl}$ in a litre, when no starch was formed. Lesage came to the general conclusion that the amount of starch decreases as the amount of sodium chloride increases, but not in the same degree. Richter ${ }^{3}$ found that many freshwater Algae can be accustomed to solutions of sodium chloride, provided the adaptation is not too forcible. Plasmolysis was never observed in experiments in which the increase in the percentage of the salt was gradual and spread over a considerable period. At the end of each successive adaptation, i.e. the point at which the plant became fully acclimatized, there was a marked increase in the amount of starch formed and stored, and this was

1 Lesage ('81).

- A considerable amount of work has been done by Strange (92), Janse (87), Oltmanns ("95), and others on the effect of concentration of the medium, bat the standpoint has been almost entirely that of growth and development.

2 Richter ('92), p. 55 . 
wholly or partly consumed during the next period of adaptation to a slightly stronger solution.

On the whole I found that Ulva was very sensitive to the amount of sodium chloride present in the solution. In a solution containing only 0.005 per cent. $\mathrm{NaCl}$ in distilled water, I obtained a 'moderate' amount of starch in six days in February, and a similar amount in 0.01 per cent. in a parallel culture. This was a larger amount of starch than I ever obtained in distilled water. Another culture in 0.1 per cent. under the same conditions and in the same time gave a 'large' amount of starch. It was found that the amount of starch formed in parallel cultures of the same duration increased up to a little beyond 2.5 per cent., and on the whole the largest amount of starch was obtained in solutions of this strength. It would be perhaps stretching the capacity of the starch-scale too far to say when the exact maximum was reached, a result which would depend to some extent, no doubt, on the vitality of the individual. As far as my experiments go I should be inclined to estimate the maximum of concentration as between one and five per cent. Experiments with higher percentages showed that the assimilation became smaller, as was expected from results of the observers already mentioned. The cause of this diminution is not very clear. It is true that plasmolysis may have taken place, a point which, from the difficulties which Ulva presented in the extreme smallness of its cells, I made no attempt to determine here or in other cases. But plasmolysis does not necessarily imply inhibition of carbon-assimilation, for it has been found that plasmolysed cells can assimilate. The effect is more probably due to the large quantity of the salt within the cells hindering the metabolism. The highest percentage of $\mathrm{NaCl}$ used was 7.5 per cent. in tap water, and, as the following experiment shows, the amount of starch was sensibly less. 
Experiment VIII. April 15, 1900. Ulva in a solution of $\mathrm{NaCl}$ in tap water.

\begin{tabular}{|c|c|l|l|l|}
\hline Dare. & Days. & $2.5 \% \mathrm{NaCl}$. & $5 \% \mathrm{NaCl}$ & $7.5 \% \mathrm{NaCl}$ \\
\hline Apr. 16 & $\mathrm{I}$ & moderate & little & trace \\
Apr. I8 & 3 & large & moderate & little \\
Apr. 20 & 5 & large & large & noderate \\
\hline
\end{tabular}

Any direct attempt to estimate the effect of the total absence of sodium chloride, and more especially of the element sodium, would necessitate an exceedingly difficult and laborious piece of research. For such, the most pedantically accurate experiments, as well as the most stringent precautions, would alone suffice. In the first place it would be exceedingly difficult to obtain Ulva free from starch and in good condition, without any trace of the sodium chloride from the sea water in which it was darkened. Glass vessels could not be used, and the water could not be distilled from glass retorts. Lastly, perhaps the most insuperable difficulty of all would be the air, which always contains sodium in the shape of dust. The complete absence of sodium would therefore be very difficult to insure. Pfeffer ${ }^{1}$ says that 'seaweeds have not up to the present time ${ }^{2}$ been cultivated in the absence of sodium chloride,' nor ' has it been found that plants frequenting saline habitats can exist without sodium.'

It was no part of my object to solve the problem of the complete absence of sodium chloride. I am able, however, to offer indirect evidence from experiments in which the amount of sodium chloride was apparently only very small, if any at all was present. I may here anticipate the results obtained from the experiments in which a single one of the principal salts in sea water, other than $\mathrm{Na} \mathrm{Cl}$, was alone present in the medium. A fuller account of these experiments is contained

$$
3 \text { Pfeffer ('00), p. 411. } 21897 \text {. }
$$


in the two following sections. In these it is possible that in all cases a small amount of $\mathrm{NaCl}$ may have been present as a residuum of the original sea water. This amount, however, seems to have been quite negligible, for the following reasons.

As already stated, I found that Ulva in 0.005 per cent. $\mathrm{Na} \mathrm{Cl}$ in distilled water gave a 'moderate' amount of starch in a week at the end of April. In experiments with $\mathrm{K} \mathrm{Cl}$ alone (vide section 6 ), in which the percentage in distilled water was 0.07 (the amount in sea water), I was unable to obtain more than a 'trace' of starch. Now, if the impurity of $\mathrm{NaCl}$ present were as large as .005 per cent., there would seem to be no reason why a 'moderate' amount of starch would not have been formed, despite the presence of .07 per . cent. $\mathrm{K} \mathrm{Cl}$; for the element potassium is absolutely essential to the plant. Further, in no case in which a single one of the salts $\mathrm{Mg} \mathrm{Cl}_{2}, \mathrm{MgSO}_{4}, \mathrm{Ca} \mathrm{SO}_{1}$, and $\mathrm{KCl}$ was used alone, in any percentage that I experimented with, did I obtain a ' moderate' amount of starch. The small amount of starch found might be accounted for in some cases through the medium being too dilute, but if $\mathrm{K} \mathrm{Cl}$ were as favourable to carbon-assimilation as $\mathrm{NaCl}$, a solution of 2 per cent. $\mathrm{KCl}$, which is equivalent to about I. 6 per cent. $\mathrm{NaCl}$, should have given a 'large' amount of starch.within a week, as was -found with this percentage of the latter salt; whereas only a 'trace' was obtained. It would therefore seem that, if these results with chlorides and sulphates of potassium, magnesium, and calcium hold good, the amount of $\mathrm{NaCl}$ as an impurity is so small as to be negligible, in fact, that it may be considered as absent altogether. The lack of even a moderate amount of starch-accumulation, which was characteristic of experiments with solutions of these salts, cannot, I think, be in any way due to the starch being used up for growth, as in nearly all cases, especially in solutions of $\mathrm{Ca} \mathrm{SO}_{4}$ and $\mathrm{KCl}$, the plants become obviously unhealthy after a short time. 


\section{Conclusions.}

The general result of these experiments was that sodium chloride, in the absence of other salts, is highly favourable to carbon-assimilation, and the presence of this salt alone in the medium, if in sufficient degree of concentration, can induce a considerable amount, but not quite the maximum, of starch-storage. On the other hand, an almost complete absence of sodium chloride was found to cause a marked inhibition of the carbon-assimilation. It would appear, therefore, that sodium chloride is a salt indispensable to Ulva, and perhaps to other marine Algae, for the maintenance of carbon-assimilation.

The physiological explanation, which is provisionally suggested here, is that sodium chloride is a food-substance essential to the metabolism of the Alga. It is not of course necessary, as Richards ${ }^{1}$ has recently pointed out, that a substance which by its presence acts as a stimulus to growth or carbon-assimilation should be actually used as a foodmaterial by the plant. There is, however, some evidence from recent research for the view that sodium chloride plays a more essential part in the economy of these plants than that of a mere stimulus. It is an undeniable conclusion,. which has served as the starting-point for the researches of Schimper and others, that the cell-sap in such plants is never entirely free from this salt. Diels ${ }^{2}$, in a recent paper, has shown experimentally, that when a Halophyte is cultivated in distilled water there is a removal of the contained sodium chloride from the tissues. By estimating the quantity of $\mathrm{NaCl}$ in the ash, he found that 5 grams of the leaf of Cakile maritima, Scop., growing on the outer sand-dunes of the coast, contained I.2 per cent. $\mathrm{NaCl}$. After 5 days' cultivation in distilled water, 5 grams of the leaf contained only 39 per cent. $\mathrm{NaCl}$. These results were confirmed by experiments on Salicornia herbacea, $L$. In one case the diminution in the

\footnotetext{
1 Richards ('07), p. 676 .
}

, Diels ('08). 
amount of $\mathrm{NaCl}$ during a week's cultivation in distilled water was 21.87 per cent. Diels concludes that the chloride is decomposed within the plant, especially when the $\mathrm{NaCl}$ in the cell-sap tends to rise beyond a certain definite degree of concentration. He connects the decomposition of the chloride with the free organic acids, which Kraus ${ }^{1}$ and others have shown to be present in Halophytes; probably as a result of restricted gaseous exchange, and the defective combustion of the carbohydrate. In the Halophytes which Diels experimented with (Cakile maritima, Scop., Arenaria.(Honckenya) peploides, L. \&c.), malic acid was found to be present; and Diels concluded that possibly the sodium resulting from the decomposition of $\mathrm{NaCl}$ united with the organic acid, arid that sodium malate was formed in the first place from the decomposition of the chloride. This latter conclusion is admittedly conjectural, and not founded on experimental evidence. With regard to the chlorine set free from the $\mathrm{NaCl}$, Diels concludes that it unites with the hydrogen of the organic acid, and is returned to the exterior by secretion of the roots. This would seem to be a most remarkable statement, and can only be taken, I think, as showing that Diels was unable in any way to trace the ultimate fate of the chlorine.

Hansteen ${ }^{2}$ has concluded that $\mathrm{NaCl}$, and also $\mathrm{K} \mathrm{Cl}$, stand in a definite relation to the formation of proteids from amides and carbohydrates. If $\mathrm{NaCl}$ is present in a cell capable of proteid-formation and of carbon-assimilation, one of two things would seem to happen. In the one case, the presence of salt tends to prevent the glucose reacting with the amide, and the cell remains poor in proteids but rich in carbohydrates. The other case seems to present reverse conditions; an abnormal acceleration of proteid being formed at the expense of the carbohydrate. Hansteen thinks that it depends on the quantity of the chloride present which reaction takes place.

In the case of proteid formation it is probable, therefore,

$$
1 \text { Kraus ('86). }
$$$$
2 \text { Hansteen ('96). }
$$ 


\section{Arber.-On the Effect of Salts on thi Assimilation}

that sodium chloride acts as a controlling agent, but I am inclined to think that the large amount of the removal of $\mathrm{NaCl}$ from the leaf, as found by Diels, and the extreme importance of this salt as shown here, are strongly in favour of the view that in such Halophytes as Ulva the $\mathrm{NaCl}$ is also essential for the metabolism. Whether it is the acid or the base, or both, which is necessary, is a question which only further work can answer.

Lastly it is interesting to contrast the results obtained with Ulva with the conclusions which have been drawn from nonhalophytic Phanerogams. Schimper ${ }^{1}$ has concluded that for the great majority of plants $\mathrm{NaCl}$ is of no importance as a food material, and further that in salt-solutions the assimilation is inhibited to such a degree that starch and sugar are no longer produced. Stahl ${ }^{2}$, Lesage ${ }^{3}$, and Dassonville ${ }^{4}$, among others, have also concluded that salt-solutions tend to injure or diminish the carbon-assimilatory apparatus. Richter ${ }^{\circ}$ has however pointed out that these results do not necessarily hold in the case of freshwater Algae.

\section{Șetion VI. Other Chlorides in Sea Water.}

Besides $\mathrm{NaCl}$, two other chlorides-magnesium chloride and potassium chloride-occur in sea water in the proportion of 0.3 per cent. and 0.07 per cent. respectively. Potassium is an essential element to all plants, and in case of Ulva is derived entirely from the small proportion of $\mathrm{KCl}$ in sea water. Magnesium is also essential, and is obtained from the chloride, sulphate, or the very small amount of nitrate in sea water. Experiments were made in which Ulva was exposed in a solution made up of distilled water and all the principal salts of sea water in the proportions which they there occur, with the exception of $\mathrm{Mg} \mathrm{Cl}_{8}$ in one case, and $\mathrm{K} \mathrm{Cl}$ in the other. The absence of either salt did not seem to affect the amount of starch formed in any way.

Lesage ('90).

1 Schimper ( 98 ), p. 98 , and ('91), p. 26.
Stahl (94), p. 136.

- Richter ('92). 
of Carbon Dioxide in Ulva latissima, L.' 6I

Experiment IX. Artificial sea water without $\mathrm{Mg} \mathrm{Cl}_{2}$

\begin{tabular}{|c|c|l|}
\hline \multicolumn{3}{|c|}{ Begun Jan. I9, I900. } \\
\hline Date. & Days. & Amount of Starch. \\
\hline Jan. 20 & I & trace \\
Jan. 23 & 4 & moderate \\
Jan. 29 & I0 & large \\
\hline \multicolumn{3}{|c|}{ Begun Jan. 30, 1900. } \\
\hline Feb. 14 & I4 & maximam \\
Mar. 1 & 29 & maximum \\
\hline
\end{tabular}

Experiment $\mathbf{X}$. Artificial sea water without $\mathrm{K} \mathrm{Cl}$.

\begin{tabular}{|c|c|c|}
\hline \multicolumn{3}{|c|}{ Begun Jan I9, Igoo. } \\
\hline Date. & Days. & Amount of Starch. \\
\hline Jan. 20 & $\mathbf{I}$ & moderate \\
\hline Jan. 23 & + & trace \\
\hline Jan. 29 & 10 & moderate \\
\hline \multicolumn{3}{|c|}{ Begun Jan. 30, I900. } \\
\hline Feb. 14 & 14 & maximum \\
\hline Mar. I & 29 & maximam \\
\hline
\end{tabular}

Experiment XI. Control. Natural sea water.

\begin{tabular}{|c|c|l|}
\hline \multicolumn{3}{|c|}{ Begun Jan. 19, I900. } \\
\hline Date. & Days. & Amownt of Starch. \\
\hline Jan. 20 & 1 & trace \\
Jan. 23 & 4 & little \\
Jan. 29 & 10 & moderate \\
\hline \multicolumn{3}{|c|}{ Began Jan. 30, I900. } \\
\hline Feb. 14 & I4 & maximum \\
Mar. I & 29 & maximum \\
\hline
\end{tabular}




\section{Arber.-On the Effect of Salts on the Assimilation}

The conclusion which I came to was that the absence of normal amounts of $\mathrm{MgCl}_{2}$ or $\mathrm{K} \mathrm{Cl}$ did not have any appreciable effect, and that these salts alone would not have a very great influence in maintaining the normal amount of carbon-assimilation. In Exp. IX, sufficient magnesium was probably. present for the needs of the plant in the magnesium sulphate, and from Exp. X, I gathered that the plant could manage for some little time without access to potassium.

Experiments were also made in which Ulva was cultivated in various percentages of $\mathrm{Mg} \mathrm{Cl}_{2}$ and $\mathrm{K} \mathrm{Cl}$, all other salts being, as far as possible, absent.

$$
\text { (A) } \mathrm{Mg} \mathrm{Cl}_{2} \text {. }
$$

This series of experiments was unfortunately left until the summer was advanced, and for this reason I was not able to carry them as far as I could have wished, and the deductions which I have drawn must be regarded as provisional. Solutions were tried which contained 0.31 per cent. (the amount in sea water), I per cent. and 2 per cent. $\mathrm{Mg} \mathrm{Cl}_{2}$ made up with distilled water. Two series of each of these percentages gave, after repeated testings, either a 'trace' or a 'little,' the same amount which would have been obtained in distilled water alone. In no case was a 'moderate' amount obtained; and after a short time the Alga did not appear to be in a very flourishing condition.

(B) $\mathrm{K} \mathrm{Cl}$.

In the case of this salt a larger number of experiments were made, and under more favourable conditions than with $\mathrm{Mg} \mathrm{Cl}_{\chi}$. Solutions of 0.07 per cent., .5 per cent., 1 per cent., and 2 per cent. $\mathrm{K} \mathrm{Cl}$ were used. They all gave similar results. Either the amount of starch was nil, or a 'trace' only was found. In one instance the amount was almost a 'little,' which was the largest degree of starch I could obtain. In less than a week the Alga usually became obviously unhealthy. 
of Carbon Dioxide in Ulva latissima, L. $\quad 63$

The conclusion with regard to these chlorides (provisional in the case of $\mathrm{Mg} \mathrm{Cl}_{8}$ ) was that the presence of either salt by itself in any percentage tried was not favourable to the maximum, or even to a moderate degree of carbon-assimilation. In the case of $\mathrm{K} \mathrm{Cl}$ the amount of starch was even smaller in many cases than that which would have been formed in distilled water alone.

(C) $\mathrm{Na} \mathrm{Br}$.

A few experiments were made with sodium bromide to see whether this salt could take the place of the similar salt $\mathrm{NaCl}$. The concentrations used were $\mathrm{I}, 2$, and 2.5 per cent. $\mathrm{NaBr}$. Six experiments with these percentages all gave very similar results. Some starch was formed in all cases, but a 'little' was the largest amount obtained after repeated testings for a week or more. Bromides are known to be non-injurious if sufficiently dilute, but as far as these experiments go $\mathrm{NaBr}$ did not seem able to take the place of $\mathrm{NaCl}$ in regard to carbon-assimilation.

\section{Section ViI, Sulphates.}

The two sulphates which occur in sea water are $\mathrm{MgSO}_{4}$ ( 0.2 per cent.), and $\mathrm{Ca} \mathrm{SO}_{4}$ (0.1 per cent.). Calcium, and probably also magnesium, are essential in the case of the higher Algae, as has been shown by the recent researches of Molisch ", Klebs ${ }^{2}$, Benecke ${ }^{3}$, and Loew ${ }^{4}$.

Experiments were made with an artificial sea water, in which all the principal salts were present in the usual proportions, with the exception of magnesium sulphate in the one case, and calcium sulphate in the other. Distilled water was used as before and the Clva freed as far as possible from sea water beforehand. In neither case did the absence of these salts seem to affect the carbon-assimilation.

1 Molisch (95).

'Benecke ('98).
' Klebs ('96).

' Loew (98). 
64 Arber.-On the Effect of Salts on the Assimilation

Experiment XII. Artificial sea water without $\mathrm{Mg} \mathrm{SO}_{4}$.

\begin{tabular}{|c|c|c|}
\hline \multicolumn{3}{|c|}{ Begun Jan. I9, rgoo. } \\
\hline Date. & Days. & Amount of Starch. \\
\hline $\begin{array}{l}\text { Jan. } 20 \\
\text { Jan. } 23 \\
\text { Jan. } 29\end{array}$ & $\begin{array}{c}1 \\
4 \\
10\end{array}$ & $\begin{array}{l}\text { moderate } \\
\text { moderate } \\
1\end{array}$ \\
\hline \multicolumn{3}{|c|}{ Begun Jan. 30, 1900. } \\
\hline $\begin{array}{l}\text { Feb. I4 } \\
\text { Mar. I }\end{array}$ & $\begin{array}{l}14 \\
29\end{array}$ & $\begin{array}{l}\text { maximum } \\
\text { maximum }\end{array}$ \\
\hline
\end{tabular}

Experiment XIII. Artificial sea water without $\mathrm{Ca} \mathrm{SO}_{4}$.

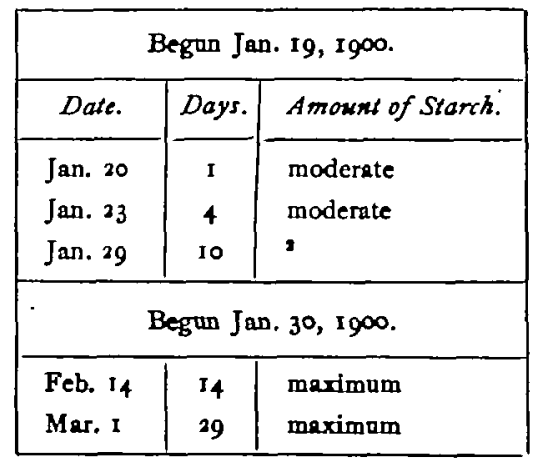

The control in sea water was the same as in Experiment $\mathrm{XI}$, and in nearly all cases the amount of starch formed during these experiments was fully equal to the control. Enteromorpha gave very similar results. In the first experiment sufficient magnesium was available from the $\mathrm{MgCl}_{2}$ present, and in both a sulphate was present. The only special point of interest was that the absence of calcium in

1 Ulva was not estimated bere, but Enteromonoha gave a moderate account.

- Énteromorpha moderate. 
of Carbon Dioxide in Ulva latissima, L. 65

Experiment XIII did not seem to affect the amount of carbon-assimilation. Whether the plant can get on without it for a time if magnesium is present, or whether reserves of calcium exist in the plant; did not fall within the province of this paper to determine. Perhaps a very little calcium only is needed, and this may have crept in as an impurity in these relatively rough experiments. The conclusion drawn, however, was that the absence of either of these salts did not markedly affect the power of carbon-assimilation.

As in the case of the chlorides, experiments were made with various percentages of these salts alone.

\section{(A) $\mathrm{CaSO}_{4}$.}

Two series of experiments were made; in one the amount was the same as in sea water ('I4 per cent.), and the other was a saturated solution. In the latter case, 5 grams $\mathrm{Ca} \mathrm{SO}_{4}$, finely powdered, were placed in 500 c.c. distilled water, and constantly stirred. After allowing the solution to stand for some hours, the undissolved $\mathrm{CaSO}_{4}$ was filtered off. The solution, therefore, contained considerably less than I per cent. $\mathrm{CaSO}_{4}$. Starch-free Ulva was allowed to remain for 8 days or more in these two solutions, but after frequent testings, with two series of experiments, I never obtained more than a 'trace,' while in the great majority of cases no starch whatever was found. The Ulva began to fragment, and show other signs of becoming unhealthy after a few days. These experiments were conducted in the latter part of June, when, as already explained, the conditions were unfavourable. The conclusion which, I think, may be provisionally drawn is that $\mathrm{CaSO}_{4}$ alone cannot take the place of $\mathrm{NaCl}$ in regard to carbon-assimilation.

\section{(B) $\mathrm{Mg} \mathrm{SO}_{4}$}

Magnesium sulphate is readily soluble in water. Solutions containing 0.23 per cent. of this salt in distilled water (the amount in sea water) gave in all cases a 'trace' or a 'little' 


\section{Arber.-On the Effect of Salts on the Assimilation}

starch. In experiments with 1 or 2 per cent. $\mathrm{Mg} \mathrm{SO}_{4} \mathrm{I}$ failed to get a larger amount of starch. I therefore concluded that $\mathrm{Mg} \mathrm{SO}_{4}$ was a salt less favourable to carbon-assimilation than $\mathrm{NaCl}$.

$$
\text { (C) } \mathrm{Na}_{2} \mathrm{SO}_{4} \text {. }
$$

Glauber's salt does not occur in sea water, but two experiments were tried in the hope that a larger amount of starch would be obtained than in the case of the other sulphates. A 2 per cent. solution was used, and gave similar results; after 3 days a 'trace,' after 7 days a 'little.'

The general conclusion of these experiments with sulphates alone was similar to those obtained with chlorides other than $\mathrm{NaCl}$. The amount of starch was never greater than a 'little,' often only a 'trace,' a result which would have been obtained by using distilled water alone. The experiments with $\mathrm{Ca} \mathrm{SO}_{4}$ seemed to give even a worse result.

\section{Section XiII. Conclusions.}

There has been a tendency in recent work to call greater attention to the importance of the absorption of inorganic salts for the maintenance of carbon-assimilation. Stahl ${ }^{1}$ in particular has adopted this standpoint in regard to the theory of the biology of nyctitropism.

From my experiments it seems clear that in the case of Ulva a marked inhibition of the power of carbon-assimilation can be caused by the absence of suitable or necessary inorganic salts, and especially by an almost complete absence of sodium chloride. The absence of a certain salt from the medium may cause an inhibition just as much as the presence of an unfavourable salt in the medium. In Ulva, and probably in other plants of similar structure and habitat, sodium chloride was found to have a peculiar value in regard to carbon-assimilation, and although a full measure of carbonassimilation is doubtless only reached when the whole or

$$
\text { 'Stahl ('97), p. 82, \&c. }
$$


of Carbon Dioxide in Ulva latissima, L. 67

most of the other salts in sea, water are present, none of these salts could be found to replace sodium chloride in this respect ${ }^{1}$. In most of the experiments in which an inhibition was caused by the presence or absence of a certain salt, such an. inhibition was rarely absolute at first. Even in experiments with distilled water, a very small amount of starch was detected, and this may have been due to reserves of inorganic material within the plant. If these conditions were continued, not only did the inhibition become absolute, but such conditions were generally found to be fatal to the plant.

Ulva is a member of a special biological group of plants, the Halophytes, and probably an obligate Halophyte. In such no doubt there are special requirements which may have in part arisen as adaptations to the environment, and which are largely or totally absent in other groups of plants. Consequently such conclusions as are here drawn are not general, but only applicable to such plants as are Halophytes, and perhaps only to obligate Halophytes.

The following is a short summary of the chief results obtained :-

I. Distilled water for a short time allows of a very small amount of carbon-assimilation, but is quickly fatal through the absence of all essential inorganic salts.

2. Tap water, containing only a small percentage of salts, will permit of a comparatively large amount of carbonassimilation, but not the maximum.

3. Sea water, being the natural medium of these plants, allows of the maximum of carbon-assimilation within the shortest time.

4. Sodium chloride seems to be an absolutely indispensable salt to the medium for even a moderate amount of carbonassimilation. From indirect evidence, in which this salt was as far as possible absent, in rough experiments, there was found to be a marked inhibition.

1 It is possible that by a process of accommodation $\mathrm{MgCl}_{2}$, or some other salt, could be made to take the place of $\mathrm{Na} \mathrm{Cl}$, but this is a point which it did not fall within the province of this Fork to determine. 
68 Arber.-On the Effect of Salts on the Assimilation

5. The maximum degree of concentration of sodium chloride is probably between $I$ and 5 per cent.

6 . None of the other salts which form the principal constituents of sea water can take the place of $\mathrm{NaCl}$ in any degree of concentration experimented with. The same remark applies to $\mathrm{Na} \mathrm{Br}, \mathrm{Na}_{2} \mathrm{SO}_{4}$.

7. The absence of any one of the principal salts in sea water other than sodium chloride, provided the others were present in the normal amounts, did not cause any inhibition.

8. The presence of either $\mathrm{Ca} \mathrm{SO}_{4}$ or $\mathrm{K} \mathrm{Cl}$ in distilled water seemed to inhibit the carbon-assimilation almost completely, especially when in greater percentage than the normal amounts in sea water. 


\section{of Carbon Dioxide in Ulva latissima, L. 69}

\section{BIBLIOGRAPHY.}

Arber, E. A. N. ('00) : Brit. Ass. Rep. Bradford, I900.

Benecke, W. ('98): Bot. Zeit., 1898 .

Dassonville, Ch. (96): Rev. génér. de Bot, tome viii, 1896.

DIELs, L. ('98) : Jahrb. für wiss. Bot, Bd. xxxii, ı 898.

Hansteen, B. ('96) : Berichte d. deut. bot. Gesellsch., Bd. xiv, I896.

Harvey, W. H. ('46): Phycologia Britannica, vol. iv, 1846-5I.

JANSE, J. M. ('87): Bot. Centralbl., Bd. xxxii, I887.

Johnson, S. W. ('69) : 'How Crops Grow:' London, 1869.

Kle bs, G. ('96) : 'Die Bedingungen der Fortpflanz. bei einigen Algen a. Pilzen.' Jena, 1896 .

Kraus, C. ('86) : Abhandl. d. Naturf.-Gesellsch. Halle, Bd. xvi, 1886.

Lesage, P. ('Y0) : Rev. génér. de Bot., tome ii, 1890.

('91): Compt. Rendus, tome cxii, I89I.

LoEw, O. ('98): Bot. Centralbl., Bd. lxriv, 1898.

Molisch, H. ('95) : Sitzangsb. der k. Akad. Wien, Bd. civ, Abth. i, I895; Bd. cv, Abth. i, I 896 .

Noll, F. ('92) : Flora, I892.

Oltmanns, F. ('92): Jahrb. für wiss. Bot., Bd. Ixiii, 1892.

('95): Flora, I 895 .

Preffer, W. ('00): Physiology of Plants (Trans. by Ewart), vol. i, I 900.

Richards, H. M. ('97): Jahrb. für wiss. Bot., Bd. Ixx, I 897 .

Richter, A. (92): Flora, 1892.

- SACHS, J. ('88) : Arbeiten des Bot. Inst. in Würzbarg, Bd. iii, I888.

DE SAUSSURB, N. T. : vide Johngon ('69).

SChtMPer, A. F. W. ('91): 'Die indomalayische Strandflora.' Jena, 1891. (98): 'Pflanzen-Geographie.' Jena, 1898.

Staht, E. (94): Bot Zeit., 1894.

STANGe, B. ('92): Bot. Zeit., 1892.

ThOR PE, T. E. : 'Inorg. Chem.,' vol. i, and edit., N.D.

ThorPe, T. E, and Moretox, E. H. (71) : Ann. Chem. and Phar., rol. clviil, I87I (vide Thorpe).

Tilden, W. A. (89): Watts' 'Inorg. Chem,' 1889.

WARD, H. M. (99) : Ann, of Bot., 1899. 